\title{
Socialist Postmodernism. The Case of the Late Soviet Lithuanian Architecture
}

\author{
Martynas Mankus, Vilnius Gediminas Technical University
}

\begin{abstract}
The aesthetical and cultural features of Lithuanian architecture related to Postmodernism are closely connected to socio-political, socioeconomic and sociocultural transformations at the end of the 20th century. The article presents an interpretation of modernisation-related processes, which affected and shaped the Lithuanian architecture of the late socialism. The expression of Postmodernism is analysed as an alternative to industrialization, typification and mass production. The aim of the article is to establish and analyse the social factors that have determined the appearance of postmodern architecture and its functioning in society, and to reveal ideological and aesthetical intersections of architecture, and the relationship between late socialism and Postmodernism.
\end{abstract}

Keywords - Hybridity, late socialism, Modern and postmodern architecture, postcolonialism.

\section{INTRODUCTION}

Chronologically, the late Soviet period architecture in Lithuania was signified by its transition from Modernism to Postmodernism. The umbrella-like concept of Postmodernism covers different spheres of culture that influenced the architecture in the 1970s and 1980s, as described by Ch. Jencks [1], H. Klotz [2], F. Jameson [3] and others. Postmodernism developed as a reaction to Modernism and its shortcomings, as well as a reflection of the postmodern condition. If the postmodernity is considered a specific phenomenon of the Western world, its transition beyond the boundaries of this space would be a result of local perception and conceptions. Thus, Postmodernism in Lithuania is a special case, existing within specific ideological regime of socialism, which has transcended all areas of cultural and social life.

Influenced by Postmodernism, Lithuanian architects, similar to their western counterparts, were interested in history, context and meaning. Although, with the only official ideological model of the 'socialist realism' being applied to architecture, as well as to other areas of culture and art, any theoretical discussions on the expression of Modernism or Postmodernism were hardly imaginable. While assessing different aspects of Postmodernism in Soviet architecture, urbanism and public spaces, an ideological component should be distinguished, which would hierarchize objects according to their importance and value in the socio-political system of the time. Writing about politics and architecture in Soviet Lithuania, architecture researcher V. Petrulis notices "the importance of distinguishing the two levels - the official and unofficial - in exploring the architectural culture, as any other form of culture, within this period" [4, 107]. Whereas anthropologist A. Yurchak suggests another interpretation rejecting the dichotomies of oppression and resistance, truth and lies, official and unofficial culture, the state and the people, public self and private self.
According to him, such contrapositions "overlook the complex meanings, values, ideals and realities that constituted the Soviet system and, defying clear-cut divisions, existed both in harmony with the state's announced goals and in spite of them" [5, 283]. The approaches of postcolonial theory discussed in the article help to bypass such critically limiting schemes of resistance and collaboration and to focus on more complex cultural processes.

The analysis based on the theory of postcolonialism allows exploring, what meanings were attributed to a specific architectural expression by the Soviet empire and what values could render architecture in occupied countries. Such complex correlation is noticed after analysing the history of Soviet Lithuania (as a periphery of the Soviet Union), where the Soviet regime, both in its rhetoric and practice, had applied the methods of destruction and remaking of other cultures according to its own cultural models, so typical to colonizers. The postcolonial approach also provides important insights on how in architectural practice of the period under discussion it was looked for a separation between "own" and "other", and the cultural identity, which was of great importance on the agenda of Lithuanian postmodern architecture.

The applied research methods do not refer to a unified methodology but rather to various methodological approaches (artistic, historical, comparative) and theories (social history of architecture, discourse and postcolonial theories), which help to investigate specific theoretical topics, sociocultural contexts, particular design objects, and the ways of how the architecture of Postmodernism was perceived and interpreted in a specific geographic and cultural space, shaped (or influenced) by the state socialism. The empirical research was based on the selection and analysis of Lithuanian and foreign sources, texts, illustrations and drawings.

\section{The Contradictions Between Late Soviet Postmodernism and Modernism}

Postmodern architecture in the article is understood as a prethought architectural strategy and historical phenomenon, which has emerged in Western Europe and the US in the 1960s. The term itself is related to Modernism and, if not in the cultural, then at least in chronological aspect means the period following Modernism. Interpreting Postmodernism as a response to Modernism, of the contradictions between Modernism and Postmodernism in the Soviet environment should be discussed. It is noticeable that the phenomenon of Modernism is not totally universal and monolithic, therefore the Lithuanian modernism of the Soviet period could be defined by multiple (alternative, local, parallel, etc.) conceptions of modernity, generally applied to the outskirts 

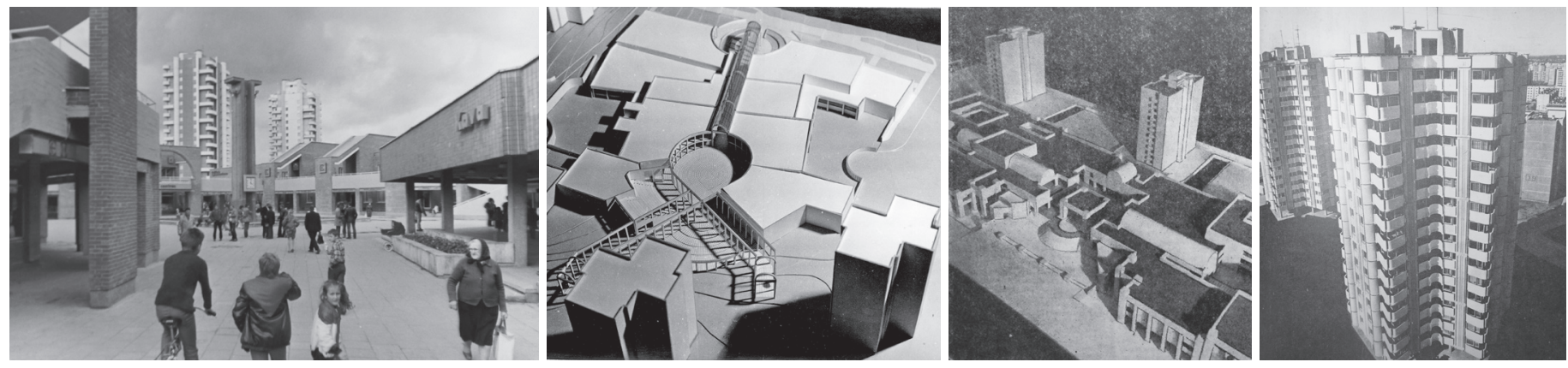

Fig. 1. Public service centre Šeškine in Vilnius, by architects G. Baravykas, K. Pempè, G. Ramunis, G. Dindienè (1985) [Photographer: unknown, Vilnius Regional State Archives, ATP-1337].
Fig. 2. Project of a public service centre in Siauliai, by K. Jurènas, A. Černiaus kas (1981) [Photography: from the archive of A Cerniauskas].
Fig. 3. Public service centre Kalniečiai in Kaunas, by E. Miliūnas (1989) [Photography: from Statyba ir architektüra, 1983-01].
Fig. 4. Residential district Kalniečiai in Kaunas, by A. Steponavičius, G. Miškinienè, A. Krasilnikova (19751985) [Photograph: R. Rakauskas, 1984]. of European 'metropolis' (speaking in the Cold War terms - to the second and third worlds). In order to describe the transformations of modernity in non-western countries, the method specified by historian D. Chakrabarty could be helpful: "The idea is to write into the history of modernity the ambivalences, contradictions, the use of force, and the tragedies and ironies that attend it" $[6,43]$. In the Soviet environment, a local expression of Soviet modernity has been defined by researchers as 'Socialist Modernism' [7], [8], while speaking of the Baltic States, increasingly often the term 'Baltic Modernism' is applied [7], [9]. The architecture of Postmodernism in the Soviet environment was aimed against unification, typification and standardization of architecture related to the modernization phenomena. Until the late Soviet period, architecture essentially was the environment-unifying factor: in the social aspect, the entire territory of the country was planned based on uniform principles and producing unified environment. While discussing the Soviet cities, philosopher N. Milerius highlights the global synchronisation strategies resulting in "a peculiar synchronicity of life in different and often, as it seemed, historically and culturally incompatible spaces. Of course, a citizen from Tallinn or Vilnius visiting Alma-Ata or Dushanbe felt like he/she was in a historically, culturally, geographically and architecturally radically different environment, but because of such synchronized strategies and tactics, such newly found otherness was easily convertible into a recognizable uniformed Soviet life model" [10]. Apart from the 'soft' (daily life) synchronization, the 'hard' one - the urbanized environment - also existed. This statement has been supported by the (post)socialist city researchers [11]-[14], distinguishing its uniformity, massiveness, lack of service infrastructure. When comparing the features of a socialist city to a capitalist, sociologist I. Szelényi characterises them in such a way: "less diversity, less economizing of space, less marginality" [13]. Although he defines thus the general urban situation, these characteristic features describe quite clearly the monotonous architectural expression. Therefore, architects had continuously supported the idea of competitions for designing important objects instead of applying typical solutions, or even tried to avoid appointments in typified design planning departments.

In the 1980s, one of the most noticeable features of Soviet architecture related to Modernism - residential districts, a striking example of industrialization, typification and application of the mass production elements - became an object of criticism. Individual expression of Lithuanian architects, who followed the postmodern tendencies in the West, was often an antithesis (critique or attempt of improvement) towards the unifying architecture of these districts. Such attempts to improve them by suggesting alternative aesthetics and composition can be noticed when analysing the architecture of public service centres intended to serve these districts. By the end of $1980 \mathrm{~s}$, they were started being interpreted as labyrinth-like fragments, reminding of the old town morphology and proposing a counterbalance to modernist free planning. For example, public service centre Šeškine in Vilnius (by architects G. Baravykas, K. Pempè, G. Ramunis, G. Dindienè and others, 1985, (Fig. 1)) contrasted with the prefabricated district environment, both by its material (red brick) and structure (forming a semi-closed square). Similar composition was chosen for a competition project of a public service centre in Šiauliai (by architects K. Jurenas, A. Černiauskas, 1981, (Fig. 2)) - a central passage of the building connected the street with the internal square, which, in its turn, was linked with the extensions of the inner paths of the block. Another example of similarly composed, 'splintered' structure is public service centre Kalniečiai in Kaunas (by architect E. Miliūnas, 1989, (Fig. 3)). The object standing by the street was designed like a gate to the residential district (Fig. 4), while the 'porous' structure of the complex allowed passing it through in several directions. It was criticized because of its level differences, multiple staircases inside the building and for being dysfunctional, but the author admitted his old town inspirations and confirmed that he had deliberately created the complex three-dimensional space. These buildings of public service centres signified a new approach in the design process of public-service centres in residential districts. According to it, the objects characteristic to Modernism with squares in front of them were replaced with elaborated com- 


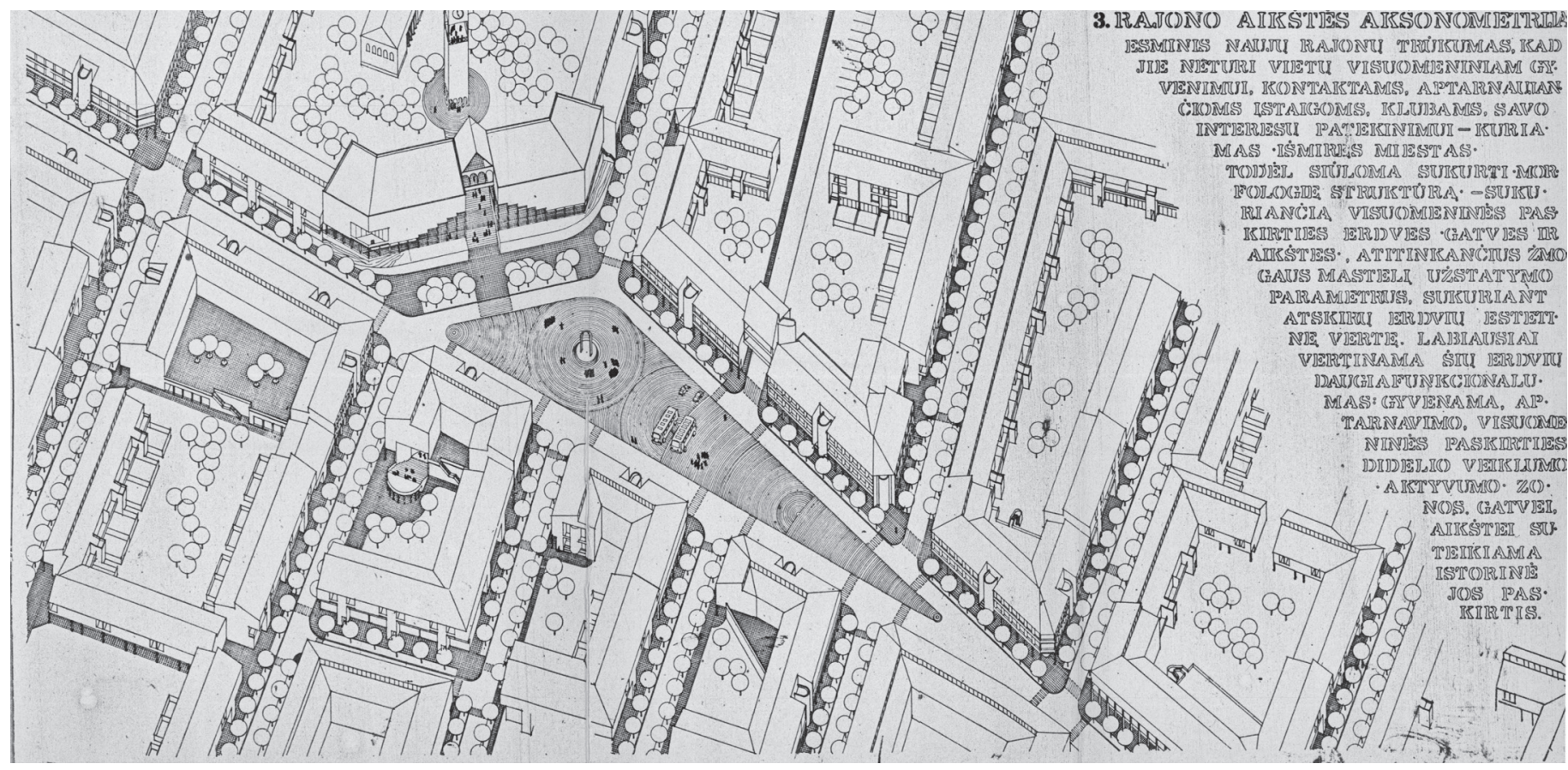

Fig. 5. Project of Ežeras quarter in Šiauliai, by A. Černiauskas (1983) [Photography from the archive of A. Černiauskas].

plexes with a bit introvert inner spaces and sophisticated spatial structures; from 'things in the space' buildings became objects 'concentrating the space'. The contextual approach of postmodern urbanism allowed architects to pursue different and ostensibly more humane scale of spaces. For example, the unrealized design project of Ežeras quarter in Šiauliai (by architect A. Černiauskas, 1983, (Fig. 5)) not only focused on its poly-functional necessity, but also suggested application of the traditional urban planning principles (perimeter development, highlighting the importance of streets and squares).

The above-mentioned cases could be seen as balancing between Late-Modern and Postmodern modes of expression, as proposed by $\mathrm{Ch}$. Jencks and others. The architectural taxonomies are usually overlapping, they boundaries are blurred. However, what these cases do have in common is a definite step outside the confines of modernism.

Another expression related to Postmodernism, the regionalism and contextualism as a way to convey the need for universal civilization by using the elements indirectly obtained from the peculiarities of a specific place, was also especially noticeable in Lithuanian architecture. As architect G. Baravykas has stated while highlighting the significance of place-making of architecture, "our architects understand Postmodernism as contextualism, as attempts to get inspiration from the traditions of our country [...]" $[15,14]$. It can be stated in general that before 1990 the architecture of Postmodernism in Lithuania was on the margins of the Soviet culture and reflected the non-ideologised trends of architectural development and unrestricted creation.
II. Correlations of Postmodernism, Late Socialism and Postcolonialism in Architecture

The end of the 20th century, marked by the special socio-political, socio-economic and socio-cultural breaking points - the end of the Cold War, establishment of capitalism, globalisation and rapid development of technology - is also significant as a finale of different phenomena and paradigms, which at first sight looked immovable: socialism, colonial world, modernity. This has affected the analysis of architectural phenomena and conceptions of its expression in broader cultural field: the contexts of late socialism, postcolonialism and Postmodernism. The period of late socialism resembles a definition of Postmodernism presented by sociologist and philosopher Z. Bauman: "What has happened in recent years could be articulated as the appearance of a vantage point, which allows to approach the modernity itself as an enclosed object, an essentially complete product, an episode in history, with a clearly defined end, as well as a beginning" $[16,117]$. Therefore, according to philosopher A. Erjavec, "the late socialism is 'post-socialism' - the declaration of the end of socialism within the socialism itself" $[17,3]$. Regardless the striking ideological differences of socialism and capitalism, Z. Bauman thinks that the foundation of both models was the industry based on science and management, as well as general acceptance of homogenous culture, both of them being "the two legs, on which the modernity stood" [18, 48]. It was socialism, which made the modernist dream of unlimited industrial progress real, therefore socialist cities have become archetypal examples of Modernism. According to architectural researcher S. Hirt, "post-socialist cities represent textbook examples of urban post-modernisation, as much 


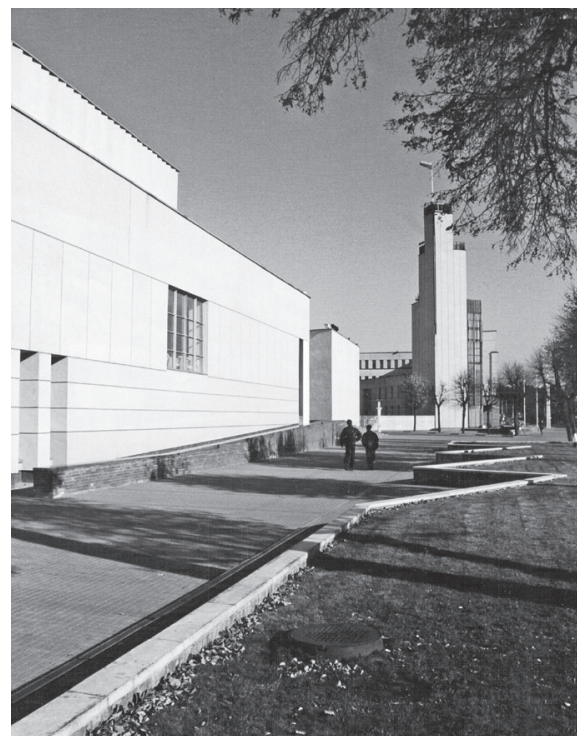

Fig. 6. Alytus town Municipality building, by Saulius Juškys (1985-1989) [Photography: S. Juškys].

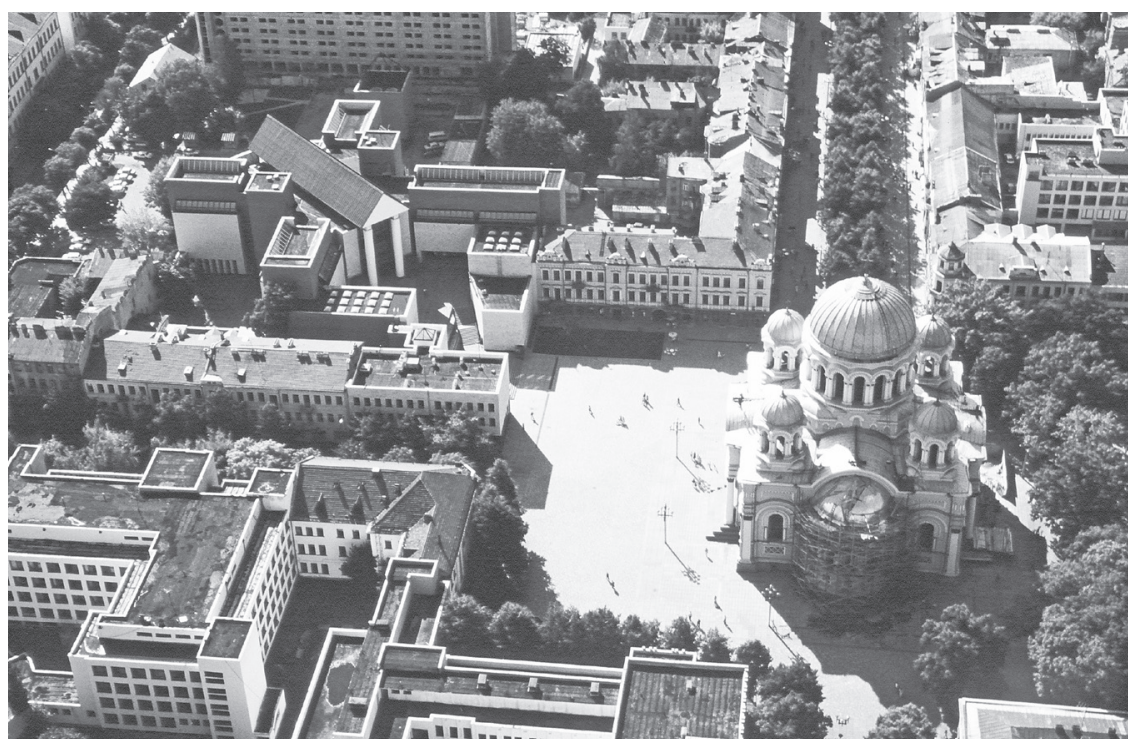

Fig. 7. M. Žilinskas Art Gallery in Kaunas, by S. Juškys, K. Kisielius, E. Miliūnas (1981-1988) [Photography: from the archive of S. Juškys]. as socialist cities epitomised the essential legacy of modernist urbanity" [11, 785].

The issues of local architectural expression (including postmodern) have been increasingly often discussed in the light of the theory of postcolonialism. Entrenched in the 1990s, this theory, covering the area of cultures that had been exposed to colonialism, political issues of power and dominance, presently has been broadly applied in literature and art. According to the approach of the founders of the postcolonialism theory E. W. Said and H. K. Bhabha, any colonial order is based on the unequal relationship, built on power, in which a coloniser is considered civilised and thus more superior than a barbarous and backward colony (subaltern) [19]. Historically, the methodological approach of this theory has been applied to the states of Asia, Africa and the Middle East, or the so-called 'Third World' countries, which suffered from the impact of colonialism and imperialism of the Western European countries. Yet, in recent years, they have been often used when analysing the cultural situation of the former Eastern Bloc countries.

One of the aspects of such postcolonial study approach is questioning the relationship between the centre and periphery as stable hierarchic relations. Although the concepts of the centre and periphery are traditionally defined according to the hierarchy of political power, researchers have shown that in different areas and periods the vectors of power influence are not necessarily stable and effective. Therefore, this leaves some space for movements, ideas and processes, independent from the centre, to prosper. Representatives of postcolonial studies state that the relationship between a centre and periphery is relative and may change or even be reversed in certain circumstances. In the Soviet space, the Baltic countries perceived themselves quite opposite from being a part of European society. In his article "Is the Post- in
Postcolonial the Post- in Post-Soviet? Toward a Global Postcolonial Critique", literature expert D. C. Moore distinguishes the Baltic and central European countries as a special case of 'reverse-cultural colonisation', where an exploiter is considered to be of lower culture than the exploited, and the conquered territories are understood "as prizes rather than burdens needing civilizing from their occupiers" [20, 121].

According to M. Rudovska, who analysed the Soviet period architecture in Latvia, the distinction between 'the other' (Soviet Russia) and 'own' architecture was typical for the architectural thought of the time. She states that similar approach was characteristic to all architecture development periods in her country: Stalinism, Modernism and Postmodernism [21, 76]. In parallel to this, the intolerance to 'imported' forms of architectural expression by the first post-war generation of Lithuanian architects could be looked upon from the perspective of national identity. In 1955, while speaking at the 2 nd meeting of the Union of Lithuanian Architects, architect A. Nasvytis summarized the situation: "First of all, it is noticeable that almost all new buildings, without any exception, fail to match to the architecture of Vilnius formed throughout ages [...]. These new buildings erected in Vilnius radiate some kind of bad smell of low-quality pseudo-classicism and somehow vulgar decorated recent Moscow structures [...]. While following our common sense, we can reach a conclusion that only local architects, the representatives of local school of architecture, are able to convey the national character of architecture" [22, 34].

Sometime later, such search for the national character had become an object of interest also to architects influenced by Postmodernism. One of the strategies of such architecture - contextualism and interpretation of historical forms - was based not only on the generalised legacy of architectural history but also on the 
original local architecture of interwar Modernism. Postmodern architecture in Kaunas may be distinguished as a special case, which, besides other influences, invoked the authentic historical legacy of the city. The interpretations of interwar architecture can be noticed in a remarkable number of designs by Kaunas architects. For example, the building of Alytus town Municipality designed by Saulius Juškys (1985-1986, implemented in 19871989, (Fig. 6)), shows a traditional composition of complex (the object forms a regular mini-quarter of the town) and modelling of the building plastics (the graphics of the facades, composition containing a tower reminding of the tower of Vytautas Magnus War Museum building). Architecture researcher V. Petrušonis wrote about another brilliant specimen of Lithuanian Postmodernism, M. Žilinskas Picture Gallery in Kaunas (Fig. 7): "when E. Miliūnas and his friends designed M. Žilinskas Picture Gallery before the restoration of Independence, it was a silent resistance - its temperate monumentality was designed to emphasise the greatness of our nation" [23, 24]. The issue of resistance as cultural defiance in architecture is quite complicated, although it may be stated that in the late Soviet years some space was found for a certain dissident practice. Analysing such practices in different ideological contexts, architecture historian I. Weizman stated: "During the Cold War, architectural dissent was articulated by refusal to participate in state projects, by subversion of the norms and language of dominant architecture, or by retreat into a private domain of paper architecture or clandestine educational practice" [24, 109].

Distinguishing the trends of Sovietisation and nationality in the architecture of the Soviet period, the question of evaluation arises. Architecture historian M. Drèmaite, evaluating Vilnius architecture of the second half of the 20th century, notices: "it is not only difficult, but also a bit incorrect to look upon it through the binary lens of opposition of Sovietism - Lithuanian national identity [...] in such ideologized approach, the criterion of architecture quality vanishes" $[25,103]$. The architectural heritage of this period is interesting first of all for its hybrid merge of trends of Sovietism and nationalism.

\section{Conclusion}

Postmodern architecture in Soviet Lithuania was a result of complex and ambiguous circumstances and ambitions. On the one hand, it was obviously an imported product, born outside the Soviet environment. On the other hand, this global phenomenon of culture and architecture had served, apart from other things, as a local instrument for expression. Attention to context, history, phenomenology of a place was related to giving a sense of purpose to the environment and the past.

The architecture of Postmodernism suggested an alternative to Modernism not only in the aspect of aesthetic-stylistic expression, but also as a social and cultural ambition to improve the urbanized environment and an attempt to find an expression resonating the national identity. Such trends of regionalism and contextualism manifested themselves in the complex circumstances amid the search for Soviet ideology (national in form, but socialist in con- tent) and national identity (search for traditional values as national emancipation), and thus determined the cultural and stylistic hybridity of architecture.

\section{REFERENCES}

1. Jencks, Ch. Language of Post-Modern architecture. New York: Rizzoli, $1977,204 \mathrm{p}$.

2. Klotz, H. The History of Postmodern Architecture. Cambridge and London: The MIT Press, 1988, $478 \mathrm{p}$.

3. Jameson, F. Postmodernism, or, The Cultural Logic of Late Capitalism. Durham, NC: Duke University Press, 1990, $461 \mathrm{p}$.

4. Petrulis, V. Politika architektūroje : reiškinio prielaidos sovietmečio Lietuvoje. Darbai ir dienos. 2007 (48), pl. 101-118.

5. Yurchak, A. Everything was forever, until it was no more. Princeton: Princeton University Press, 2005, $352 \mathrm{p}$.

6. Chakrabarty, D. Provincializing Europe : Postcolonial thought and historical difference. Princeton: Princeton University Press, 2000,336 p.

7. Ritter, K. Shapiro-Obermair, E., Wachter, A. Soviet Modernism 1955 1991 : An Unknown History (Arhitekturzentrum Wien, ed.). Zürich: Park Books, 2012,360 p.

8. Socialist Realism and Socialist Modernism : World Heritage Proposals from Central and Eastern Europe. ICOMOS - Journal of the German National Committee VIII. Berlin: Hendrik Baessler Verlag, 2013, 144 p.

9. Drèmaitė, M. Baltic Modernism : Architecture and Housing in Soviet Lithuania. Berlin: DOM publishers, 2017, $250 \mathrm{p}$

10. Milerius, N. Breaking point : from soviet to post-soviet city [online]. ARCHITECTURE [publication] FUND [cited 12.09.2017]. http://www. archfondas.lt/leidiniu/alf-03/ese/nerijus-milerius

11. Hirt, A. S. Landscapes of Postmodernity: Changes in the Built Fabric of Belgrade and Sofia Since the End of Socialism. Urban Geography, Vol. 29, Issue 8, 2008. pp. 785-810. http://dx.doi.org/10.2747/0272-3638.29.8.785.

12. Hirt, A. S. Iron curtains : gates, suburbs, and privatization of space in the post-socialist city. Oxford: Wiley-Blackwell, 2012. $254 \mathrm{p}$

13. Cities After Socialism: Urban and Regional Change and Conflict in Post-Socialist Societies (G. Andrusz, M. Harloe, I. Szelenyi, eds). Malden, MA: Blackwell, 1996. $356 \mathrm{p}$.

14. The Urban Mosaic of Post-Socialist Europe: Space, Institutions and Policy (S.Tsenkova, Z. Nedovic-Budic, eds.). Heidelberg: Physica, 2006, 390 p.

15. Baravykas, G. Vakaru vejai. Krantai, 1990 kovas, Nr. 15, pp. 10-14.

16. Bauman, Z. Legislators and Interpreters : On modernity, post-modernity, and intellectuals. Cambridge, UK: Polity Press; Oxford: In association with B. Blackwell, 1987, $209 \mathrm{p}$.

17. Postmodernism and the Postsocialist Condition: Politicized Art under Late Socialism (A. Erjavec, ed). Berkeley, Los Angeles: University of California Press, 2003, $297 \mathrm{p}$.

18. Global Modernities (M. Featherstone, S. Lash, R. Robertson, eds.). Thousand Oaks, CA: Sage, 1995, $304 \mathrm{p}$

19. Spivak, G. Ch. Can the Subaltern Speak? Marxism and the Interpretation of Culture (C. Nelson, L. Grossberg, eds.) London: Macmillan, 1988, pp. 271-313.

20. Moore, D. Ch. Is the Post- in Postcolonial the Post- in Post-Soviet? Toward a Global Postcolonial Critique. PMLA, Vol. 116, No. 1, Special Topic: Globalizing Literary Studies (Jan., 2001), pp. 111-128.

21. Rudovska, M. Expired Monuments : Case Studies on Soviet-era Architecture in Latvia through the Kaleidoscope of Postcolonialism. Studies on Art and Architecture, Vol. 21/3-4, 2012, pp. 76-93.

22. Materials from the Second Congress of the LSSR Union of Architects held during October 14-16, 1955, LLMA, f. 87, ap. 1, b. 442, 1. 30.

23. Petrušonis, V. Egiptas Kauno centre. Arkitektas, 1997. Vol. 5, Issue 1, pl. $22-25$.

24. The SAGE Handbook of Architectural Theory (G. C. Crysler, C. Cairns, H. Heynen, eds). London: Sage, 2012, 753 p.

25. Drẻmaitè, M. Sovietmečio paveldas Vilniaus architektūroje : tarp lietuviškumo ir sovietiškumo. Naujasis Vilniaus perskaitymas : didieji Lietuvos istoriniai pasakojimai ir daugiakultüris miesto paveldas. (A. Bumblauskas, Š. Liekis, G. Potašenko, sud.). Vilnius: Vilniaus universiteto leidykla, 2009, pl. 79-103. 


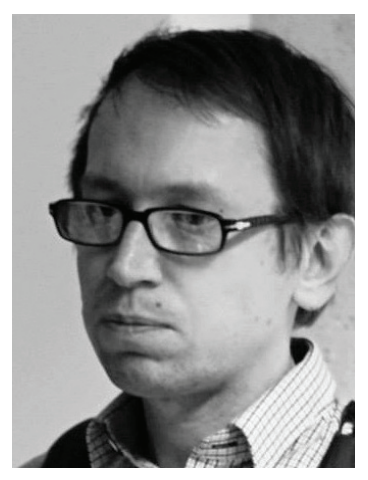

Martynas Mankus obtained a Bachelor degree in Architecture in 1994, and a Master degree in Architecture in 1996, from Vilnius Gediminas Technical University. Since 2013, he has been a PhD student with the Faculty of Architecture, VGTU. He is currently working on doctoral thesis Manifestations of Postmodern Ideas in Lithuanian Architecture at the end of the 20th - the beginning of the 21st centu$r y$ under the supervision of scientific advisor Dr. Tomas Grunskis.

Since 1996, he has been working as an architect with several architectural companies. He is a co-author of several implemented public and residential buildings, participant of different creative workshops and competitions in Lithuania and abroad. He has authored and co-authored several scientific articles and frequently writes for architectural magazines, most recently for Archiforma, Project Baltia and MONU. His research area is modern and postmodern architecture. In spring 2017, together with Tomas Grunskis he organized a series of lectures Post-architecture at the National Gallery of Art in Vilnius.

He is a certified architect (reg. No A914), registered by Lithuanian Chamber of Architects, and a member of Lithuanian Union of Architects.

\section{Contact Data}

\section{Martynas Mankus}

Department of Architectural Fundamentals and Theory

Vilnius Gediminas Technical University

Address: 26/1 Pylimo Av., Vilnius, LT-01132, Lithuania

Phone: +37061626831

E-mail: martynas.mankus@gmail.com 